ZOOLOGIA 30 (1): 43-48, February, 2013

http://dx.doi.org/10.1590/S1984-46702013000100005

\title{
Size-selective predation of the catfish Pimelodus pintado (Siluriformes: Pimelodidae) on the golden mussel Limnoperna fortunei (Bivalvia: Mytilidae)
}

\author{
João P. Vieira \& Michelle N. Lopes
}

Laboratório de Ictiologia, Universidade Federal do Rio Grande. Avenida Itália km 8, 96201-900 Rio Grande, RS, Brazil. E-mail: vieira@mikrus.com.br

\begin{abstract}
This paper describes the size-selective predation on Limnoperna fortunei (Dunker, 1857) by Pimelodus pintado (Azpelicueta, Lundberg \& Loureiro, 2008) from the time it arrived at the Mirim Lagoon basin (2005). Sampling was carried out using bottom trawl in depths of 3-6 m, from January to November 2005, and from October to November 2008. Pimelodus pintado began to prey upon L. fortunei soon after its arrival (austral spring of 2005). On the spring of 2008 , L. fortunei was found to be the most important food item of $P$. pintado. The variation in length of the mussels $(0.7$ $3.2 \mathrm{~cm}$, with a mode of $1.3 \mathrm{~cm}$ ) indicates that the species is now fully established in the system. Our data indicates that large individuals of $P$. pintado incorporate more mussels in their diets than small individuals. However, regardless of their size, P. pintado individuals predate only on small $(<1.4 \mathrm{~cm})$ representatives of $L$. fortunei. This prey size corresponds to a phase when the mussel is more mobile and readily available for fish. Larger, more aggregated prey groups that are attached to hard substrates are avoided by fish predators.
\end{abstract}

KEY WORDS. Diet; freshwater invasion; opportunistic predator; Mirim Lagoon.

The Asian freshwater golden mussel, Limnoperna fortunei (Dunker, 1857), was first recorded in the Americas in 1991, from the coast of the Rio de la Plata, by PAstorino et al. (1993). Limnoperna fortunei has the capability of colonizing a wide range of habitats and has few natural predators, widely colonizing freshwater and estuarine environments in the Neotropical region. Since its introduction, the species has expanded its range to Argentina, Brazil, Paraguay and Uruguay (DARRIgran et al. 1998, Darrigran \& Ezcurra de Drago 2000, Darrigran 2002, Oliveira et al. 2006).

In 1998, the Asian freshwater golden mussel was recorded at the northern reaches of the Patos Lagoon drainage basin (MANsur et al. 1999, 2003) and, in the next years, it was found in the southern portion of the basin in densities of up to 140,000 ind $/ \mathrm{m}^{2}$. After that, population densities stabilized at averages $60,000 \mathrm{ind} / \mathrm{m}^{2}$ (Mansur et al. 2003). The golden mussel invaded the Mirim Lagoon in 2005 through the São Gonçalo Channel, which connects the Mirim and Patos Lagoons (LANGone 2005, Burns et al. 2006b, Coluing et al. 2012, Lopes \& Vieira 2012).

There is little question now that catastrophic biological events like these can profoundly affect entire ecosystems to the point that the invader species monopolizes a large proportion of the resources available (Sylvester et al. 2005, DARRIGRAN $\&$ Damborenea 2011). The cascading effects of such trophic web disruptions can be extremely important (Power 1992, Ruetz et al. 2002, Thorp \& CASper 2003). The high densities of golden mussel and the fact that individuals become fixed to the sub- strate by their byssal threads create a new microenvironment. This microenvironment, in turn provides a new habitat for some epifaunal species and, at the same time, can lead to the displacement of other benthic organisms (SANTos et al. 2012). Since its invasion of South America, L. fortunei has threatened the survival and modified the natural occurrence and abundance of several native macroinvertebrate species (DARRIGRAN et al. 1998, Darrigran 2002, Santos et al. 2012), including the Anomura crab Aegla platensis Schmitt, 1942 in the São Gonçalo Channel (Lopes et al. 2009).

The predation strength of fish upon the golden mussel ranges from negligible to efficient, when the total control of the mussel's population growth is achieved (STEWART et al. 1998, BARTSCH et al. 2005). In some cases, mussel predators showed increased productivity and growth as a result of the new food supply (Poddubny 1966, Boltovskoy et al. 2006, Karatayev et al. 2007). Ancillary data on Argentine freshwater fish yields support to the above conclusions, suggesting that $L$. fortunei may have had a positive effect on fish biomass in Neotropical systems (Boltovskoy et al. 2006).

Catfish of the genus Pimelodus have omnivorous feeding habits (GARCIA et al. 2006,2007whichare characterized by a generalist feeding behavior and the opportunistical exploitation of eventual peaks in prey abundance (BonetTo et al. 1963, Montalto et al. 1999, Braga 2000, Garcìa \& Protogino 2005). The use of $L$. fortunei as a food source by Pimelodus spp. (Paraná River and Patos Lagoon basin) had been previously reported 
(Montalto et al. 1999, Cataldo et al. 2002, Darrigran \& Damborenea 2011). For this reason, we hypothesized that the catfish Pimelodus pintado (Azpelicueta, Lundberg \& Loureiro, 2008) at the Mirim Lagoon would incorporate the Asian freshwater golden mussel in its diet.

The objective of this study was to describe the chronological incorporation of $L$. fortunei into the diet of $P$. pintado, from the time the prey arrived in the São Gonçalo Channel, at the Mirim Lagoon basin. Additionally, we show that P. pintado selects mussel prey within a certain size range, from the wide range of sizes available in the environment.

\section{MATERIAL AND METHODS}

The Mirim Lagoon basin is located between 31 and $34^{\circ} \mathrm{S}$ and 52 and $54^{\circ} \mathrm{W}$ in the eastern part of the South American central plains (Fig. 1). The basin area covers $62,250 \mathrm{~km}^{2}$, with $29,250 \mathrm{~km}^{2}$ in southern Brazil and the remaining 33,000 km in eastern Uruguay. The main geographical feature of this basin is the Mirim lagoon itself, with an average area of 3.749 $\mathrm{km}^{2}$ (BRACCO et al. 2005). During periods of intense rainfall, water from the Mirim Lagoon and its adjacent wetland system drain through the natural São Gonçalo Channel (75 km long, 200 to $500 \mathrm{~m}$ wide, $6 \mathrm{~m}$ maximum depth) into the Patos Lagoon, which ultimately connects with the Atlantic Ocean through the Rio Grande channel. The São Gonçalo Channel Dam divides the São Gonçalo Channel into a freshwater environment to the south and an estuarine environment to the North (Burns et al. 2006a, Moura et al. 2012).

Bottom fauna samples were obtained from the limnetic region of the São Gonçalo Channel between $31^{\circ} 48^{\prime} \mathrm{S}, 52^{\circ} 23^{\prime} \mathrm{W}$ and $32^{\circ} 7^{\prime} \mathrm{S}, 52^{\circ} 35^{\prime} \mathrm{W}$ (Fig. 1). Bottom trawl was carried 3 to $6 \mathrm{~m}$ deep, from January to November 2005, and from October to November 2008. Every season, four samplings at three different sampling areas (Dam, Tigre and Piratini), totalizing twelve samplings per season, were carried out using a fishermen's wooden boat (10.9 m long with a $60-\mathrm{Hp}$ engine). Five-minute tows (approximately $400 \mathrm{~m}$ ) were performed using a $10.5 \mathrm{~m}$ (head rope) shrimp trawl $(1.3 \mathrm{~cm}$ bar mesh wings and body with a $0.5 \mathrm{~cm}$ bar mesh cod end liner) and a pair of weighted outer doors (Lopes et al. 2009, Lopes \& VieIRA 2012).

Representatives of $P$. pintado collected in each tow were stored in separate plastic bags and fixed in $10 \%$ formaldehyde. Voucher specimens were deposited at "Coleção Ictiológica da FURG" number 6,056 (25) 6061 (6). At the laboratory, the total length (TL) of each individual was measured to the nearest millimeter. Stomachs were extracted by cutting out the esophagus and pylorus and fixed in $70 \%$ alcohol. Prey items were identified to the lowest taxonomic level, counted and grouped into categories. We determined Frequency of Occurrence (FO\%), Percent Area (PA\%) and Index of Relative Importance (IRI) of the $P$. pintado diet for samples collected during the austral summer (January and February), autumn (April), winter (July and

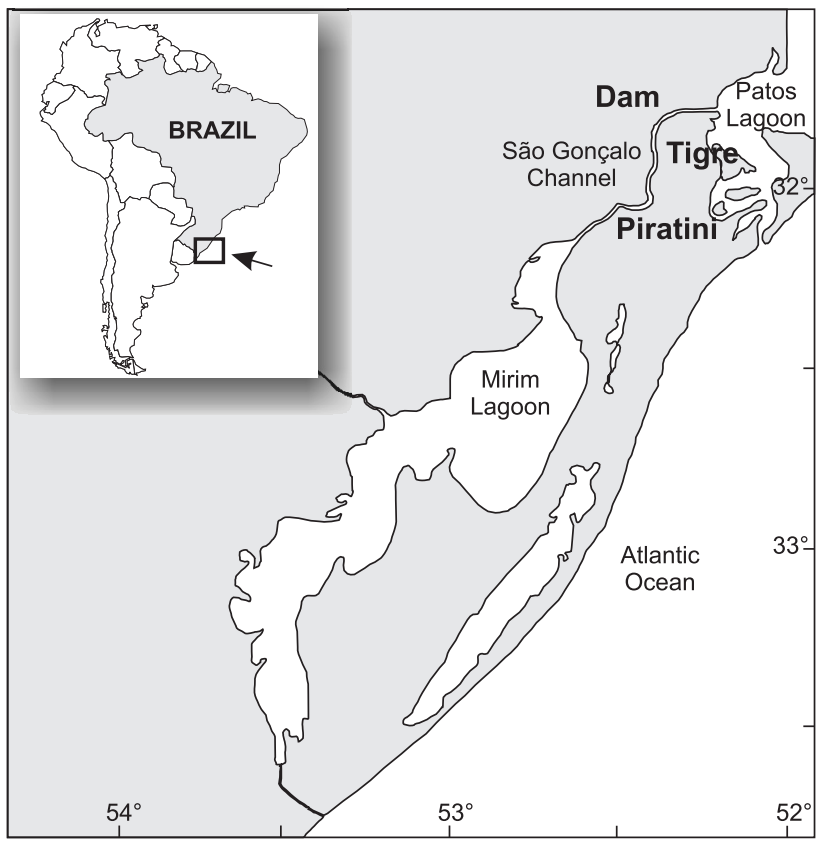

Figure.1 Mirim Lagoon (drainage basin, $62.250 \mathrm{~km}^{2}$ ) and the São Gonçalo channel that connects it with the Patos Lagoon. The limnetic region is localized southern the dam. The sampling areas are show (Dam, Tigre and Piratini).

August) and the austral spring (September, October and November) of 2005 and the austral spring (October and November) of 2008. IRI was determined as FO\% x (PN\%+PA\%), where PN\% are number percent (HysLop 1980) of each food item. We compared de relative importance of the golden museel in the stomachs of catfish sampled in the spring of 2005 with those sampled in the spring of 2008 (three years after L. fortunei occurrence was recorded in the system).

Using an electronic caliper with accuracy of $0.01 \mathrm{~mm}$, the maximum shell length of $L$. fortunei prey was measured using the individuals present in the stomachs of $P$. pintado, as well as using the specimens collected in the environment (bottom trawl, during 2008). The maximum length was considered as the distance from the anterior end, situated just above and ahead of the umbones, until the rear end of the shell (Mansur et al. 1987).

After logarithmic transformation $\left(\log _{10}+1\right)$ the differences between the sizes of golden mussels found in the digestive tract of different sizes classes of $P$. pintado were tested using one-way analysis of variance (size class 10-15 cm TL, $\mathrm{N}=6$; size class 15 $20 \mathrm{~cm} \mathrm{TL}, \mathrm{N}=52$; size class 20-25 cm TL, $\mathrm{N}=51$; size class 25$30 \mathrm{~cm} \mathrm{TL}, \mathrm{N}=38$ ) (ZAR 1999). The differences between the sizes of golden mussels found in the digestive tract of all $P$. pintado and those collected in the environment were tested using the nonparametric Kolmogorov-Smirnov test (SOKAL \& ROHLF 1995). 


\section{RESULTS}

Asian golden mussels were not observed in the stomachs of catfish collected during the austral summer, autumn or winter of 2005. The first record of the mussel was during the austral spring (September, October and November) of 2005, when it was found in $21.8 \%$ of the 180 stomachs of $P$. pintado $(10-30$ $\mathrm{cm}$ TL). In this period, L. fortunei represented $1.8 \%$ of the Relative Importance Index (IRI) in the diet to P. pintado (Table I).

During the austral spring of 2005, L. fortunei individuals were only observed in the stomachs of fish larger than $14 \mathrm{~cm}$, and large fish incorporated more mussels in their diets (Fig. 2). The length golden mussel shells $(0.3-1.4 \mathrm{~mm})$ found in the digestive tracts of $P$. pintado did not differ significantly among the different predator length class analyzed (Fig. 3, ANOVA, $\left.\mathrm{F}_{3,143}=0.9744, \mathrm{p}=0.407\right)$.
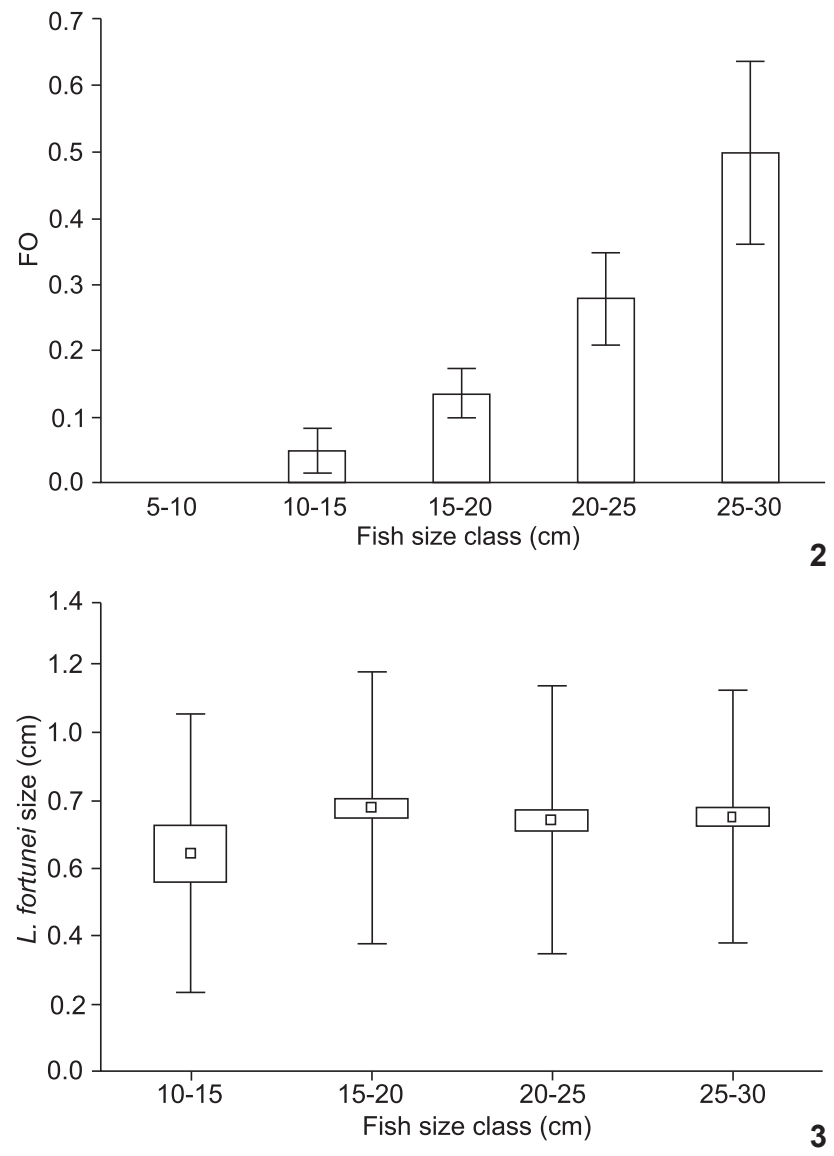

Figures 2-3. (2) Frequency of occurrence of Limnoperna fortunei in the digestive tracts of $P$. pintado at different fish size class analyzed in the spring of 2005. The line represent the standard deviation and the bars represent mean. (3) Box plot of Limnoperna fortunei shell size distribution by Pimelodus pintado size class in the spring of 2005.
In the austral spring of 2008 (Table I), L. fortunei was found in $60.8 \%$ of the 30 stomachs of $P$. pintado analyzed and was the most important food item in the diet of the cat fish (IRI = $31.4 \%)$. Specimens of $L$. fortunei $(\mathrm{N}=7789)$ collected by the shrimp trawl in 2008 were measured and compared with the 51 specimens found in the stomachs of $P$. pintado $(20.7-30.5 \mathrm{~cm}$ $\mathrm{TL}$ ) sampled in the same area. The length range of fortune of the mussel in the environment $(\mathrm{n}=7789)$ was 0.7 to $3.2 \mathrm{~cm}$, with a mode of $1.3 \mathrm{~cm} \mathrm{TL}$, and the shell length of mussels found in the in the guts $(\mathrm{n}=147)$ of $P$. pintado ranged from 0.3 to $1.4 \mathrm{~cm}$ (Fig. 4) and the nonparametric Kolmogorov-Smirnov test revealed a significant difference (Fig. 5, D = 0.82491, $\mathrm{p}<0.001$ ) between them.

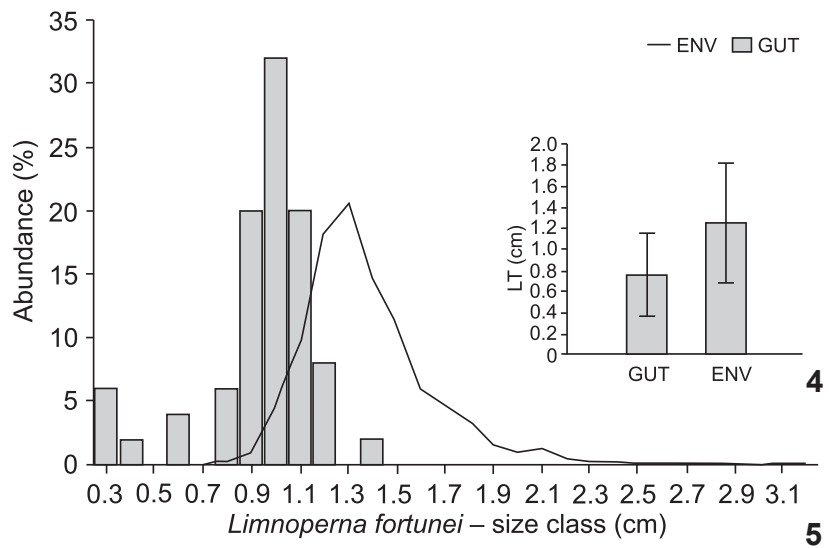

Figures 4-5. (4) Shell size distribution of Limnoperna fortunei collected in the environment (ENV), and in the guts (GUT) of Pimelodus pintado at the spring of 2008. (5) Mean size and $95 \%$ confidence interval of Limnoperna fortunei.

\section{DISCUSSION}

Boltovskoy \& Cataldo (1999) showed that during the first year of the introduction of $L$. fortunei, mussels reached up to $2.0 \mathrm{~cm}$ in length, and by the end of their second year, some reached $3.0 \mathrm{~cm}$. The maximum length of mussels in this study was $3.2 \mathrm{~cm}$. Additionally, BuRns et al. (2006b) recorded the species in the São Gonçalo Channel for the first time in 2005. Both facts suggest that the species was already fully established in São Gonçalo Channel in 2008 (Lopes \& Vieira 2012).

The mean shell length of $L$. fortunei found in the digestive tracts of $P$. pintado were similar for the different predator length classes analyzed and reached a maximum size of $1.4 \mathrm{~cm}$ (Fig. 3). Montalto et al. (1999) and Lopes \& Vieira (2012) showed that Asian golden mussels are predated in different development stages by several fish species in the Neotropical region, but small mussels $(<1.5 \mathrm{~cm})$ were more frequent and abundant in fish guts. CANTANHÊDE et al. (2008) analyzed the diet of a 
Table I. Seasonal variation of the Frequency of Occurrence (FO\%), Percentage by Number (PN\%), Percentage by Area (PA\%), and Relative Importance Index (IRI\%) of items found in the diet of Pimelodus pintado during 2005 and 2008.

\begin{tabular}{|c|c|c|c|c|c|c|c|c|c|c|c|}
\hline \multirow{3}{*}{ Items } & \multicolumn{7}{|c|}{2006} & \multirow{2}{*}{\multicolumn{4}{|c|}{$\frac{2008}{\text { Spring }}$}} \\
\hline & \multirow{2}{*}{$\frac{\text { Summer }}{\text { FO\% }}$} & \multirow{2}{*}{$\frac{\text { Autumn }}{\text { FO\% }}$} & \multirow{2}{*}{$\begin{array}{c}\text { Winter } \\
\text { FO\% }\end{array}$} & \multicolumn{4}{|c|}{ Spring } & & & & \\
\hline & & & & $\mathrm{FO} \%$ & PN\% & PA\% & IR\% & FO\% & PN\% & PA\% & IR\% \\
\hline Small crustaceans & 13.51 & 47.89 & 65.48 & 74.15 & 63.77 & 40.07 & 67.76 & 17.39 & 7.04 & 3.64 & 1.97 \\
\hline Crabs & 20.27 & 2.82 & 1.19 & 3.40 & 0.21 & 2.34 & 0.08 & 21.74 & 2.18 & 19.75 & 5.06 \\
\hline Insects & 35.14 & 60.56 & 64.29 & 57.14 & 15.33 & 19.27 & 17.40 & 65.22 & 16.26 & 8.11 & 16.85 \\
\hline L. fortunei & - & - & - & 21.77 & 5.16 & 4.49 & 1.85 & 60.87 & 18.83 & 34.77 & 31.37 \\
\hline Corbicula spp. & - & 4.23 & 11.90 & 2.72 & 0.25 & 0.12 & 0.01 & 13.04 & 1.94 & 1.02 & 0.41 \\
\hline Heliobia spp. & 27.03 & 12.68 & 7.14 & 16.33 & 3.16 & 0.87 & 0.58 & 47.83 & 51.70 & 9.20 & 30.88 \\
\hline Fish & 70.27 & 49.30 & 16.67 & 21.29 & 4.28 & 7.42 & 2.17 & 4.35 & 0.24 & 2.68 & 0.13 \\
\hline Plant & 2.70 & 35.21 & 15.48 & 39.46 & 3.23 & 22.98 & 9.10 & 52.17 & 3.88 & 17.52 & 11.84 \\
\hline Other & 9.48 & 4.23 & 2.38 & 19.73 & 1.93 & 2.07 & 0.69 & 26.09 & 1.94 & 2.98 & 1.36 \\
\hline Mineral & - & 9.86 & 4.76 & 13.61 & 2.70 & 0.37 & 0.37 & 8.70 & 0.97 & 0.32 & 0.12 \\
\hline
\end{tabular}

predator fish larger than P. pintado (Pterodoras granulosus; $17-$ $55 \mathrm{~cm} \mathrm{TL}$ ) and found similar results, whereas the size range of L. fortunei individuals ranged from 0.8 to $1.7 \mathrm{~cm}$ in mean, although the mussel is well known to reach more than $3 \mathrm{~cm}$ (Boltovskoy \& Cataldo 1999, Maroñas et al. 2003, Mansur et al. 2008).

Young and adult $L$. fortunei individuals have a considerable ability to move to new locations with some taxis, suggesting that this represents an ability to avoid predation by hiding (LOPES \& VIEIRA 2012). The distance that mussels are able to move decreases with increasing shell length, and they tend to aggregate after reaching $1.5 \mathrm{~cm}$ TL (URYu et al. 1996). The observations of the present study suggest that more mobile individuals of $L$. fortunei (smaller than $<1.4 \mathrm{~cm}$ ) are able to crawl over the bottom and are probably more readily available in the São Gonçalo Channel to fish such as P. pintado than larger and more aggregated mussels that get attached to the hard substrate. Fish with a generalist feeding behavior are good samplers of prey diversity and can easily detect new sources of food, and are flexible enough to exploit eventual peaks in prey abundance (Glova \& Sagar 1989, Mendoza-Carranza \& Vieira 2007). Then, independently from the size of individuals, the catfish under study consumes only golden mussels that are smaller than 1.4 $\mathrm{cm}$ TL, which implies that the predator prefers smaller prey because they are more readily available.

It is important to note that $L$. fortunei was first reported in the limnetic zone of the São Gonçalo Channel in January 2005 (Burns et al. 2006b). Since the diet of $P$. pintado is influenced by the availability of food in the environment, the data presented here suggest that the trend observed in this study, i.e., the absence of $L$. fortune $i$ in the stomachs of $P$. pintado from the austral summer to the winter and the presence of it in the spring 2005, is a good indicator that $L$. fortunei started to be abundant in the limnetic zone of the São Gonçalo Channel during the austral spring of 2005. At the present time, $L$. fortunei is fully established in the São Gonçalo Channel (Colling et al. 2012, Lopes \& VieIRA 2012).

Little empirical information is available to explain the success of invaders (Mansur et al. 2012). The arrival and spread of $L$. fortunei at the Mirim Lagoon will probably bring rapid changes in the benthic community as well as the displacement of other mollusk species, as described by DaRRIGAN (2002) and DaRrigran \& Damborenea (2005) for other South American fresh water habitats. Currently, unpublished data suggest that $L$. fortunei is much more abundant in the dense vegetated limnetic part of the São Gonçalo Channel (61 km long and $17 \mathrm{~m}$ wide) than in the wide open Mirim Lagoon itself $\left(3,749 \mathrm{~km}^{2}\right.$ area) which has few hard subtracts for mussel fixation (Lopes et al. 2009).

With the invasion of $L$. fortunei in the Neotropical region, dietary changes have been noted in omnivorous fishes, which have switched from a low quality, predominantly plantbased diet, to an energetically rich diet dominated by invasive mollusks (Montalto et al. 1999, Ferriz et al. 2000, Boltovskoy et al. 2006, Lopes \& VieIRA 2012). With the invasion of L. fortunei, part of the organic matter in the turbid São Gonçalo Channel will be filtered and modified into a form available to organisms that cannot feed on small particles, like fishes.

Lopes \& VieIra (2012) shows that 12 of 19 predators in the Mirin/São Gonçalo Channel feed on L. fortunei. Regardless of the size and foraging behavior of the predator, individuals smaller than $14 \mathrm{~mm}$ on average are preyed upon. The incidence of individuals of $L$. fortunei smaller than $14 \mathrm{~mm}$ in the diet of detritivorous fishes like Rineloricaria microlepdogaster and $R$. strigilata, which do are not adapted to predate on mollusks, confirms the hypothesis that individuals of golden mussel up to $14 \mathrm{~mm}$ TL are more vagile than larger individuals (URYu et al. 1996), and frequently move on the bottom of the São 
Gonçalo Channel, being more available to fish predation than individuals larger than $14 \mathrm{~mm}$ TL, which tend to be clustered or hindered in crevices of the substrate (LOPES \& VIEIRA 2012).

\section{ACKNOWLEDGEMENTS}

This work was supported by CNPq (Conselho Nacional de Desenvolvimento Científico e Tecnológico) and PELD Program (Pesquisas Ecológicas de Longa Duração). M.N.L was a former postgraduate student of Biologia de Ambientes Aquaticos Continentais, FURG.

\section{LITERATURE CITED}

BarTSCH, M.R.; L.A. BaRTSCH \& S. GUTREUTER. 2005. Strong effects of predation by fishes on an invasive macroinvertebrate in a large floodplain river. Journal North American Benthological Society 24: 168-77.

Boltovskoy, D. \& D.H. Cataldo. 1999. Population dynamics of Limnoperna fortunei, an invasive fouling mollusc, in the lower Parana River (Argentina). Biofouling 14: 255-263.

Boltovskoy, D.; N. Correa; D. Cataldo \& F. Sylvester. 2006. Dispersion and ecological impact of the invasive freshwater bivalve Limnoperna fortunei in the Río de la Plata watershed and beyond. Biological Invasions 8: 947-963.

Bonetto, A.A.; C. Pignalberi \& E. Cordiviola. 1963. Ecologia alimentaria del amarillo y moncholo, Pimelodus clarias (Bloch) y Pimelodus albicans (Valenciennes) (Pisces, Pimelodidae). Physis 24: 87-94.

Bracco, R.; L. Puerto; H. Inda \& C. Castiñeira. 2005. Mid-late Holocene cultural and environmental dynamics in Eastern Uruguay. Quaternary International 132: 37-45.

Braga, F.M. De S. 2000. Biologia e Pesca de Pimelodus maculatus (Siluriformes, Pimelodidae) no reservatório de Volta Grande, Rio Grande (MG-SP). Acta Limnologica Brasiliensia 12: $1-14$.

Burns, M.D.; A.M. Garcia; J.P. Vieira; M.A. Bemvenuti; D.M.L. MotTa Marques \& V. Condini. 2006a. Evidence of fragmentation affecting fish movement between Patos and Mirim coastal lagoons in southern Brazil. Neotropical Icthiology 4: 69-72.

Burns, M.D.; R.M. Geraldi; A.M. Garcia; C.E. Bemvenuti; R.R. Capitoli \& J.P. Vieira. 2006b. Primeiro registro de ocorrência do mexilhão dourado Limnoperna fortunei na Bacia de drenagem da Lagoa Mirim, RS, Brasil. Biociências 14: 83-83.

Cantanhêde, G.; N.S. Hahn; E.A. Gubiani \& R. Fugi. 2008. Invasive molluscs in the diet of Pterodoras granulosus (Valenciennes, 1821) (Pisces, Doradidae) in the Upper Paraná River floodplain, Brazil. Ecology of Freshwater Fish 17: 47-53.

Cataldo, D.; D.D. Boltovskoy; V. Marini \& N. Correa. 2002. Limitantes de Limnoperna fortunei en la cuenca del Plata: la predación por peces. In: Tercera jornada sobre conservación de la fauna íctica en el río Uruguay. Paysandu, Uruguay, La Comisión Administradora de Río Uruguay.
Colling, L.A.; R.M. Pinotti \& C.E. Bemvenuti. 2012. Limnoperna fortunei na Bacia da Lagoa dos Patos e Lagoa Mirim, p. 187191. In: C.P. Santos; D. Pereira; I.C.P. PaZ; L.M. Zurita; M.C.D. Mansur; M.T. Raya Rodriguez; M.V. Nerhke \& P.A. Bergonci (Eds). Moluscos límnicos invasores no Brasil: biologia, prevenção e controle. Porto Alegre, Redes Editora, 412p.

Darrigran, G. 2002. Potencial impact of filter-feeding invaders on temperate inland freshwater environments. Biological Invasions 4: 145-156.

Darrigran, G. \& E. De Drago. 2000. Invasion of Limnoperna fortunei (Dunker, 1857) (Bivalvia: Mytilidae) in South America. Revista Nautilus 114: 69-73.

Darrigran, G. \& C. Damboronea. 2005. A bioinvasion history in South America. Limnoperna fortunei (Dunker, 1857), the golden mussel. American Malacological Bulletin 20: 105-112.

Darrigran, G. \& C. Damboronea. 2011. Ecosystem engineering impacts of Limnoperna fortunei in South America. Zoological Science 28: 1-7.

Darrigran, G.; S.M. Martin; B. Gullo \& L. Armendariz. 1998. Macroinvertebrate associated to Limnoperna fortunei (Dunker, 1857) (Bivalvia, Mytilidae). Río de La Plata, Argentina. Hydrobiologia 367: 223-230.

Ferriz, R.A.; C.A. Villar; D. Colautti \& C. Bonetto. 2000. Alimentación de Pterodoras granulosus (Valenciennes) (Pisces, Doradidae) en la baja cuenca del Plata. Revista del Museo Argentino de Ciencias Naturales 2: 151-156.

Garcia, A.M.; D.J. Hoeinghaus; J.P. Vieira; K.O. Winemiller; D.M.L.M. Marques \& M.A. Bemvenuti. 2006. Preliminary examination of food web structure of Nicola Lake (Taim Hydrological System, south Brazil) using dual C and N stable isotope analyses. Neotropical Ichthyology 4: 279-284.

Garcia, A.M.; D.J. Hoeinghaus; J.P. Vieira \& K.O. Winemiller. 2007. Isotopic variation of fishes in freshwater and estuarine zones of a large subtropical coastal lagoon. Estuarine Coastal and Shelf Science 73: 399-408.

Garcìa, M.L.A. \& L.C. Protogino. 2005. Invasive freshwater molluscs are consumed by native fishes in South America. Journal of Applied Ichthyology 21: 34-38.

Glova, G.J. \& P.M. SAGAR. 1989. Prey selection by Galaxias vulgaris in the Hawkins River, New Zealand. New Zealand Journal of Marine and Freshwater Research 23: 153-161.

HysLop, E.J. 1980. Stomach contens analysis- a review of methods and their applications. Journal Fish Biology 17: 411-429.

Karatayev, A.Y.; D.K. Padilla; D. Minchim; D. Boltovskoy \& L.E. Burlakova. 2007. Changes in global economies and trade: the potential spread of exotic freshwater bivalves. Biological Invasions 9: 161-180.

LANGONE, J.A. 2005. Notas sobre el mejillón dorado Limnoperna fortunei (Dunker, 1857) (bivalvia, mytilidae) en Uruguay. Publicación extra del Museo Nacional de Historia Natural y Antropologia 1: 17.

Lopes, M. \& J.P. VieIRA. 2012. Predadores potenciais para o controle do mexilhão-dourado, p. 357-363. In: C.P. SANTOS; D. 
Pereira; I.C.P. Paz; L.M. Zurita; M.C.D. Mansur; M.T. Raya Rodriguez; M.V Nerhike \& P.A. Bergonci (Eds). Moluscos límnicos invasores no Brasil: biologia, prevenção e controle. Porto Alegre, Redes Editora, 412p.

Lopes, M.N.; J.P. VieIRA \& M.D.M. BurNs. 2009. Biofouling of the golden mussel Limnoperna fortunei (Dunker, 1857) over the Anomura crab Aegla platensis Schmitt, 1942. Pan-American Journal of Aquatic Sciences 4: 222-225.

Mansur, M.C.D.; C. Schulz \& L.M.M.P. Garces. 1987. Moluscos bivalves de água doce: Identificação dos gêneros do sul e leste do Brasil. Acta Biológica Leopoldencia 9: 181-202.

Mansur, M.C.D.; L.M.Z. Richinitti \& C.P. Santos. 1999. Limnoperna fortunei (Dunker, 1857) molusco bivalve invasor na bacia do Guaíba, Rio Grande do Sul, Brasil. Biociências 7: 147-149.

Mansur, M.C.D.; C.P. Santos; G. Darrigran; I. Heydricht; C.T. Callil \& F.R. Cardoso. 2003. Primeiros dados quail-quantitativos do mexilhão dourado, Limnoperna fortunei (Dunker), no Delta do Jacuí, no lago Guaíba e na Laguna dos Patos, Rio Grande do Sul, Brasil e alguns aspectos de sua invasão no novo ambiente. Revista Brasileira de Zoologia 20: 75-84.

Mansur, M.C.D.; H. Figueiró; C.P. Santos; L. Glock; P.E.A. Bergonci \& D. Pereira. 2008. Variação espacial do comprimento e do peso úmido total de Limnoperna fortunei (Dunker, 1857) no delta do rio Jacuí e lago Guaíba (RS, Brasil). Biotemas 21: 49-54.

Mansur, M.C.D.; C.P. Santos; D. Pereira; I.C.P. Paz; M.L.L. Zurita; M.T.R. Rodriguez; M.V. Nehrke \& P.E.A. Bergonci. 2012. Moluscos Límnicos Invasores no Brasil: biologia, prevenção, controle. Porto Alegre, Redes Editora, 412p.

Maroñas, M.E.; G.A. Darrigran; E.D. Sendra \& G. Breckon. 2003. Shell growth of the golden mussel, Limnoperna fortunei (Dunker, 1857) (Mytilidae), in the Río de la Plata, Argentina. Hydrobiologia 495: 41-45.

Mendoza-Carranza, M. \& J.P. Vieira. 2007. Whitemouth croaker Micropogonias furnieri (Desmarest, 1823) feeding strategies across four southern Brazilian estuaries. Aquatic Ecology 42 (1): 83-93.

Montalto, L.; O.B. Oliveros; I. E. De Drago \& L.D. Demonte. 1999. Peces del rio Parana Medio predadores de una especie invasora: Limnoperna fortunei (Bivalvia, Mytilidae). Revista de la Facultad de Bioquimica y Ciencias Biológicas de la Universidad Nacional del Litoral 3: 85-101.

Moura, P.M.; J.P. VieIra; A.M. Garcia. 2012. Fish abundance and species richness across an estuarine freshwater ecosystem in the Neotropics. Hydrobiologia 696: 107-122.
Oliveira, M.D.; A.M. Takeda; L.F. Barros; S.D. Barbosa; E.K. Rezende. 2006. Invasion by Limnoperna fortunei (Dunker, 1857) (Bivalvia, Mytilidae) of the Pantanal wetland, Brazil. Biological Invasions 8 (1): 97-104.

Pastorino, G.; G. Darrigran; S. Martin \& L. Lunaschi. 1993. Limnoperna fortunei (Dunker, 1857) (Mytilidae), nuevo bivalvo invasor em águas Del Rio de la Plata. Neotropica 39: 101-102.

Poddubny, A.G. 1966. Adaptive response of Rutilus rutilus to variable environmental conditions. Trudy Instiyuta Biologii Vnutrennykh Vod Akademii Nauk 10: 131-138.

Power, M.E. 1992. Habitat heterogeneity and the functional significance of fish in River Food Webs. Ecology 73: 16751688.

Ruetz, C.R.; R.M. Newman \& B. Vondracek. 2002. Top-down control in a detritus-based food web: fish, shredders and leaf breakdown. Oecologia 132: 307-315.

Santos, S.B.; S.C. Thiengo; M.A. Fernandez; I.C. Miyahira; I.C.B. Gonçalves; R.F. Ximenes; M.C.D. Mansur \& D. Pereira. 2012. Espécies de moluscos límnicos invasores no Brasil, p. 25-49. In: C.P. Santos; D. Pereira; I. C. P. Paz; L.M. Zurita; M.C.D. Mansur; M.T. Raya Rodriguez; M.V Nerhke \& P.A. Bergonci (Ed.). Moluscos límnicos invasores no Brasil: biologia, prevenção e controle. Porto Alegre, Redes Editora, 412p.

SoKal, R.R. \& F.J. Rohlf. 1995. Biometry: The Principles and Practice of Statistics in Biological Research. New York, W.H. Freeman, 937p.

Stewart, T.W.; J.G. Miner \& R.L. Lowe. 1998. A experimental analysis of crayfish (Orconectes rusticus) effects on a Dreissena dominated benthic macroinvertebrate community in western Lake Erie. Canadian Journal of Fisheries and Aquatic Sciences 55: 1043-1050.

Sylvester, F.; J. Dorado; D. Boltovskoy; A. Juàrez \& D. Cataldo. 2005. Filtration rates of the invasive pest bivalve Limnoperna fortunei as a function of size and temperature. Hydrobiologia 534: 71-80.

THORP, J.H. \& A.F. CASPER. 2003. Importance of biotic interactions in large rivers: an experiment with planktivorous fish, dreissenid mussels and zooplankton in the St. Lawrence River. River Research and Applications 19: 265-279.

URYu, Y.; K. IWASAKy \& M. Hinque. 1996. Laboratory experiments on behaviour and movement of a freshwater mussel, Limnoperna fortunei (Dunker). Journal of a Molluscan Studies 62: 327-341.

ZAR, J.H. 1999. Biostatistical Analysis. New Jersey, Prentice Hall, $662 \mathrm{p}$.

Submitted: 21.XII.2011; Accepted: 10.XII.2012.

Editorial responsibility: Adriano S. Melo 